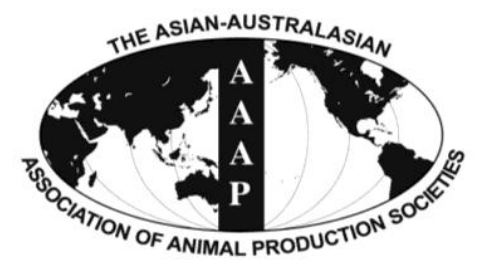

Asian Australas. J. Anim. Sci.

Vol. 26, No. 7 : 945-951 July 2013

http://dx.doi.org/10.5713/ajas.2012.12590

www.ajas.info

pISSN $1011-2367$ elSSN 1976-5517

\title{
Development of Appropriate Fibrolytic Enzyme Combination for Maize Stover and Its Effect on Rumen Fermentation in Sheep
}

\author{
T. Vijay Bhasker*, D. Nagalakshmi ${ }^{1}$, and D. Srinivasa Rao \\ Department of Animal Nutrition, College of Veterinary Science, Rajendranagar, Hyderabad-500030, India
}

\begin{abstract}
In vitro studies were undertaken to develop an appropriate fibrolytic enzymes cocktail comprising of cellulase, xylanase and $\beta$-D-glucanase for maize stover with an aim to increase its nutrient utilization in sheep. Cellulase and xylanase added individually to ground maize stover at an increasing dose rates $(0,100,200,400,800,1,600,3,200,6,400,12,800,25,600,32,000,38,400$, and 44,800 $\mathrm{IU} / \mathrm{g} \mathrm{DM})$, increased $(\mathrm{p}<0.01)$ the in vitro dry matter digestibility and in vitro sugar release. The doses selected for studying the combination effect of enzymes were 6,400 to $32,000 \mathrm{IU} / \mathrm{g}$ of cellulase and 12,800 to $44,800 \mathrm{IU} / \mathrm{g}$ of xylanase. At cellulase concentration of $6,400 \mathrm{IU} / \mathrm{g}$, IVDMD \% was higher $(\mathrm{p}<0.01)$ at higher xylanase doses $(25,600$ to $44,800 \mathrm{IU} / \mathrm{g})$. While at cellulase doses $(12,800$ to $32,000 \mathrm{IU} / \mathrm{g})$, IVDMD \% was higher at lower xylanase doses (12,800 and 25,600 IU/g) compared to higher xylanase doses (32,000 to $44,800 \mathrm{IU} / \mathrm{g}$ ). At cellulase concentration of the 6,400 to $32,000 \mathrm{IU} / \mathrm{g}$, the amount of sugar released increased $(\mathrm{p}<0.01)$ with increasing levels of xylanase concentrations except for the concentration of 44,800 IU/g. No effect of $\beta$-D-glucanase (100 to $300 \mathrm{IU} / \mathrm{g}$ ) was observed at lower cellulase-xylanase dose (cellulase-xylanase 12,800 to 12,800 IU/g). Based on the IVDMD, the enzyme combination cellulase-xylanase 12,800 to $12,800 \mathrm{IU} / \mathrm{g}$ was selected to study its effect on feed intake and rumen fermentation pattern, conducted on 12 rams (6 to 8 months; $20.34 \pm 2.369 \mathrm{~kg}$ body weight) fed $50 \%$ maize stover based TMR. The total volatile fatty acids $(\mathrm{p}<0.01)$ and ammonia-N concentration was higher in enzyme supplemented group, while no effect was observed on dry matter intake, ruminal $\mathrm{pH}$ and total nitrogen concentration. (Key Words: Exogenous Fibrolytic Enzymes, In vitro, Maize Stover, Sheep, Rumen Fermentation Pattern)
\end{abstract}

\section{INTRODUCTION}

In many tropical countries including India, ruminants subsist on low quality grasses, crop residues, and agroindustrial by-products due to the depletion of grazing lands in day to day life. These crop residues and poor quality roughages need to be processed to increase the nutrient utilization and performance of animals. Recently, supplementation of exogenous fibrolytic enzymes (EFE) as feed additives for ruminants has attracted the interests of researchers. It has been demonstrated that exogenous fibrolytic enzymes work in synergy with the endogenous rumen microbiological enzymes to enhance the digestibility and nutritive value of a high fibrous diet (Morgavi et al.,

\footnotetext{
* Corresponding Author: Vijay Bhasker. Department of Animal Nutrition, Indian Veterinary Research Institute, Bareilly, Uttar Pradesh 243122, India. Tel: +91-9493408078, E-mail: tvbs87.vety @ rediffmail.com

${ }^{1}$ Department of Animal Nutrition, College of Veterinary Science, Rajendranagar, Hyderabad, 500030, India.

Submitted Oct. 23, 2012; Accepted Dec. 27, 2012; Revised Mar. 27, 2013
}

2000), thereby increasing the economic benefits for the farmer. Most of the researchers have reported a positive effect of supplementing exogenous fibrolytic enzymes by enhancing the in vitro dry matter or fiber degradability from alfalfa hay (Eun and Beauchemin, 2007), corn stover or corn silage (Gallardo et al., 2010) and from TMR (Giraldo et al., 2008; Pinos Rodriguez et al., 2008). But most of the research on the use of EFE was focused on silages, hay and grasses. Further response to the level of enzyme addition was non-linear in vitro (Colombatto et al., 2003), indicating the need to determine the optimum dose rate of enzymes for individual feeds (Yang et al., 1999). The type of enzyme preparations or their dose levels used for hay, silages and concentrate based diets may not be applicable for the rations used in India, as the enzymes are target specific (Pinos Rodriguez et al., 2002) and scant research has been done in India on this aspect. Maize crop is one of the most important principal crops grown throughout the year in India. Moreover, Andhra Pradesh stands second in total crop yield $(4,354 \mathrm{~kg} /$ Hectare) for the year 2011 to 2012, in India. The maize stover, after harvesting of maize cobs, is 
used as staple feed for animals in most of the tropical countries like India. Any improvement in the nutrient utilization of such roughages would benefit farmers. Hence the maize stover was selected as substrate for present investigations.

In the view of the above, the proposed study was aimed to develop a suitable fibrolytic enzymes cocktail comprising of cellulase, xylanase, $\beta$-D-glucanase for maize stover by in vitro studies and later study the effect of supplementing the enzyme cocktail developed from in vitro studies on rumen fermentation in sheep.

\section{MATERIALS AND METHODS}

The EFE under investigation were Cellulase (EC 3.2.1.4), Xylanase (EC 3.2.1.8) and $\beta$-D-glucanase (EC 3.2.1.6) enzymes in powder form, had an activity of $1,000,000$ and 1,600,000 IU/g, respectively, and active in alkaline $\mathrm{pH}$, which were procured from Advanced BioAgrotech Limited, Pune, India. The source of these enzymes was Trichoderma sps. The maize stover used in the in vitro studies was of GK- 3017 variety, of 3 to 4 months maturity, procured after harvesting of maize cobs, sundried and chaffed to 1 to $2 \mathrm{~cm}$ with chaff cutter. The Organic matter (OM), Crude protein (CP), Ether extract (EE), Crude fibre (CF), Nitrogen free extract (NFE), Total ash (TA), Calcium (Ca) and Phosphorus (P) contents were $86.25,3.84,0.76,48.31,33.34,9.62,0.79$ and 0.62 percent. The stover required for in vitro studies was ground to 1 to 2 $\mathrm{mm}$ particle size with a hammer mill. The calculated concentration of enzyme was mixed manually with the stover a day before the in vitro studies had to be carried out. The in vitro dry matter digestibility (IVDMD) was studied by modified two stage in vitro technique (Goering and Van Soest, 1970) using sheep rumen liquor. The in vitro total sugar release from maize stover supplemented with various doses and combination of fibrolytic enzymes was estimated as per the procedure described by Nsereko et al. (2000). The total sugar released due to supplementing fibrolytic enzymes was quantified by the phenol-sulphuric acid method as described by Dubois et al. (1956). The assay for each sample was carried out in triplicate.

During in vivo studies, a total mixed ration (TMR) was formulated with maize stover as the sole roughage source in a roughage concentrate ratio of 50:50 (TMR-MS). The maize stover was chopped to 0.5 to $1.0 \mathrm{~cm}$ with a chaffcutter and mixed with a concentrate mixture consisting of $35 \%$ groundnut cake, $40 \%$ maize, $22 \%$ deoiled rice bran, $2 \%$ salt and $1 \%$ mineral mixture and vitamin $\mathrm{AD}_{3}(20 \mathrm{~g} / \mathrm{qt})$. The experimental ration was the TMR-MS to which the fibrolytic enzyme cocktail (cellulase-xylanase 12,800$12,800 \mathrm{IU} / \mathrm{g}$ maize stover) was supplemented (TMR-MS $+\mathrm{EFE})$. The calculated quantity of enzyme was accurately weighed and mixed in the required concentrate mixture and then mixed with chopped maize stover manually for about 10 minutes before feeding to sheep daily. The CP and CF of TMR-MS and TMR-MS+EFE were 10.43, 10.84 and 28.7, $28.25 \%$ respectively.

Twelve Deccani ram lambs (6 to 8 months) with an average body weight of $(20.34 \pm 2.369 \mathrm{~kg})$ were randomly distributed into 2 dietary groups, one group was fed with control TMR (TMR-MS) and the other group was fed on TMR supplemented with EFE (TMR-MS+EFE). The respective rations were offered twice daily at 9.00 AM and 3.00 PM to meet the nutrient requirements (ICAR, 1998). The sheep of both groups were fed the dry matter requirement as per ICAR, 1998 recommendations, during the experiment. The leftover was weighed on the next day morning before cleaning and feeding. Clean, fresh and wholesome water was made available to each group of animals at all times.

At the end of preliminary feeding period of $30 \mathrm{~d}$, rumen liquor was collected for two consecutive days from 4 lambs of each group with the help of stomach tube fitted with vacuum pump, four times a day at $0 \mathrm{~h}$ (before feeding), $2 \mathrm{~h}$, $4 \mathrm{~h}$ and $6 \mathrm{~h}$ post feeding.

Feed offered samples were analyzed for $\mathrm{CP}$ and $\mathrm{CF}$ (AOAC, 1997). The TVFA in rumen liquor samples was estimated by the method of Barnet and Reid (1957). The total nitrogen in SRL was estimated as per methods of Singh et al. (1968) and ammonia nitrogen was estimated by the method of Schwartz and Schoeman (1964). The data were subjected to statistical analysis in one-way classification under a completely randomized design using General Linear Model of SPSS 15.0. Comparison between means was done using Duncan multiple ranges test (Duncan, $1955)$ at $5 \%$ and $1 \%$ level.

\section{RESULTS AND DISCUSSION}

\section{In vitro studies}

The IVDMD and corresponding release of total sugars from maize stover for various concentrations of cellulase and xylanase enzymes is given in Table 1. The IVDMD \% was comparable among cellulase doses ranging between 0 to $3,200 \mathrm{IU} / \mathrm{g}$ DM. An improvement $(\mathrm{p}<0.01)$ in IVDMD was observed from cellulase supplementation of $6,400 \mathrm{IU} / \mathrm{g}$ DM. The digestibility was highest at cellulase concentration of $25,600 \mathrm{IU} / \mathrm{g} \mathrm{DM}$ and beyond this dose (32,000 to $448,000 \mathrm{IU} / \mathrm{g} \mathrm{DM})$, the IVDMD gradually decreased. Supplementing xylanase up to concentration of $800 \mathrm{IU} / \mathrm{g}$ DM had no effect on IVDMD and was comparable to control. The IVDMD increased $(\mathrm{p}<0.01)$ when xylanase was added at 1,600 IU/g DM and highest IVDMD was observed for doses of 25,600 and 32,000 IU/g DM and no further increase in IVDMD was recorded at higher doses of 
Table 1. In vitro DM digestibility (\%) and total sugar release (mg/g DM) from maize stover supplemented with cellulase and xylanase at various concentrations

\begin{tabular}{|c|c|c|c|c|}
\hline \multirow{2}{*}{$\begin{array}{l}\text { Enzyme concentration } \\
\text { (IU/g DM) }\end{array}$} & \multicolumn{2}{|c|}{ In vitro DM digestibility (\%) } & \multicolumn{2}{|c|}{ In vitro sugar release (mg/g DM) } \\
\hline & Cellulase & Xylanase & Cellulase & Xylanase \\
\hline 0 & $18.32^{\text {defg }}$ & $18.32^{\mathrm{ef}}$ & $3.08^{\mathrm{h}}$ & $3.08^{\mathrm{k}}$ \\
\hline 100 & $17.22^{\mathrm{g}}$ & $18.15^{\mathrm{f}}$ & $5.59^{\mathrm{fg}}$ & $5.63^{\mathrm{j}}$ \\
\hline 200 & $17.48^{\mathrm{fg}}$ & $18.57^{\mathrm{ef}}$ & $4.80^{\mathrm{g}}$ & $9.92^{\mathrm{i}}$ \\
\hline 400 & $17.90^{\text {efg }}$ & $19.10^{\mathrm{ef}}$ & $6.06^{\mathrm{fg}}$ & $11.28^{\mathrm{h}}$ \\
\hline 800 & $18.13^{\text {efg }}$ & $19.98^{\mathrm{de}}$ & $7.36^{\mathrm{de}}$ & $12.01^{\mathrm{fg}}$ \\
\hline 1,600 & $18.81^{\mathrm{def}}$ & $20.82^{\text {cd }}$ & $6.81^{\mathrm{f}}$ & $12.54^{\mathrm{f}}$ \\
\hline 3,200 & $19.17^{\mathrm{de}}$ & $21.70^{c}$ & $8.76^{\mathrm{de}}$ & $13.07^{\mathrm{f}}$ \\
\hline 6,400 & $20.79^{\mathrm{bc}}$ & $22.49^{\mathrm{bc}}$ & $9.16^{\mathrm{d}}$ & $13.08^{\mathrm{f}}$ \\
\hline 12,800 & $21.99^{\mathrm{b}}$ & $23.49^{\mathrm{ab}}$ & $10.23^{\mathrm{d}}$ & $14.58^{\mathrm{e}}$ \\
\hline 25,600 & $23.74^{\mathrm{a}}$ & $24.48^{\mathrm{a}}$ & $12.74^{\mathrm{c}}$ & $15.70^{\mathrm{d}}$ \\
\hline 32,000 & $21.16^{\mathrm{b}}$ & $25.14^{\mathrm{a}}$ & $14.38^{\mathrm{bc}}$ & $17.82^{\mathrm{c}}$ \\
\hline 38,400 & $19.30^{\mathrm{de}}$ & $23.77^{\mathrm{ab}}$ & $15.76^{b}$ & $18.20^{\mathrm{b}}$ \\
\hline 44,800 & $19.70^{\mathrm{cd}}$ & $23.97^{\mathrm{ab}}$ & $19.35^{\mathrm{a}}$ & $19.05^{\mathrm{a}}$ \\
\hline SEM & 0.379 & 0.497 & 0.658 & 0.561 \\
\hline $\mathrm{p}$ value & 0.001 & 0.001 & 0.001 & 0.001 \\
\hline
\end{tabular}

${ }^{\mathrm{a}-\mathrm{g}}$ Means with different superscripts in a column differ significantly: $\mathrm{p}<0.01$. Each value is average of triplicate; SEM = Standard error of means.

38,400 and 44,800 IU/g DM. Yu et al. (2005) reported that in vitro ruminal fluid degradability was improved $(\mathrm{p}<0.01)$ by $12 \%$ in oat hulls, $5 \%$ in wheat straw and $2 \%$ in alfalfa hay with supplementation by an enzyme mixture (Ferulic acid esterase, 6,500; xylanase, 2,048,000; cellulase, 512,000; $\beta$-glucanase, 32,000 and Endo-glucanase, 128,000 $\mathrm{IU} / \mathrm{g}$ substrate). In the present study in vitro sugar release increased $(\mathrm{p}<0.01)$ in a dose related manner for cellulase and xylanase doses from 0 to $44,800 \mathrm{IU} / \mathrm{g}$ DM and highest sugar release was observed at 44,800 IU/g DM for both the enzymes.

The esterified bond between cellulose, hemicellulose and lignin restricts the digestion of recalcitrant cereal straws by ruminal microorganisms (Waghorn and McNabb, 2003). Supplementing cellulase and xylanase at concentrations ranging from 6,400 to $25,600 \mathrm{IU} / \mathrm{g}$ and 1,600 to 32,000 $\mathrm{IU} / \mathrm{g}$ respectively, might have acted on $\beta$ 1-4 linkages of cellulose and hemicellulose (xylan), to release soluble sugars and thus facilitating the growth of microbes (Bhat and Hazelwood, 2001). Also the synergistic action of these enzymes with endogenous ruminal microbial enzymes (Morgavi et al., 2000) might have resulted in a higher IVDMD. No effect of EFE observed at lower doses (100 to $3,200 \mathrm{IU} / \mathrm{g} \mathrm{DM}$ ) for cellulase and (100 to $800 \mathrm{IU} / \mathrm{g} \mathrm{DM}$ stover) for Xylanase, which indicated that such low doses of enzymes was unable to degrade the core structure of lignin-cellulosic complexes (Nakashima and Orskov, 1989; McAllister et al., 2000).

Eun and Beauchemin (2007) reported that supplementation of EFE at of $1.4 \mathrm{mg} / \mathrm{g}$ DM improved in vitro NDF degradability up to $20.6 \%$ for alfalfa hay against control $(18.4 \%)$ and up to $60.3 \%$ for corn silage against control (13.3\%). Similarly, Wang et al. (2004) reported that spraying with enzyme mix (xylanase, $\beta$-glucanase, carboxymethylcellulase and amylase) at $1.5 \mathrm{mg} / \mathrm{gm}$ DM of wheat straw increased $(\mathrm{p}<0.05)$ digestibilities of DM, OM and total $\mathrm{N}$, compared to ammoniated wheat straw (5\% $\mathrm{NaOH}$ treated). The potentially degradable fraction of NDF and ADF increased for alfalfa hay while no differences were observed in corn stover when an in sacco trial was performed on Holstein steers to evaluate EFE having 31 cellulase units and 43.4 xylanase units supplemented at 3 $\mathrm{g} / \mathrm{kg}$ DM (Gallardo et al., 2010).

Based on the in vitro results for IVDMD and amount of the total sugars released from maize stover with supplementation of cellulase and xylanase at various concentrations, the best doses selected for cellulase were $6,400,12,800,25,600$ and 32,000 IU/g and for xylanase were $12,800,25,600,32,000,38,400$ and 44,800 IU/g. With the above concentration of enzymes, thirty combinations $(5 \times 6)$ were formulated for maize stover inclusive of unsupplemented (0 IU/g DM for cellulase and xylanase) and tested by in vitro studies (Table 2).

Significant interaction of cellulase and xylanase was observed on in vitro DM digestibility and sugar release. At a cellulase concentration of 6400 , IVDMD \% was higher $(\mathrm{p}<$ $0.01)$ at higher concentration of xylanase $(25,600$ to 44,800 $\mathrm{IU} / \mathrm{g}$ ), while at cellulase concentration of 12,800, 25,600 and 32,000 IU/g, IVDMD \% was higher at lower xylanase doses $(12,800$ and $25,600 \mathrm{IU} / \mathrm{g})$ compared to higher xylanase doses (32,000, 38,400 and 44,800 IU/g). Bhat and Hazelwood (2001) reported a synergistic effect between cellulase and xylanase to hydrolyze forage cell wall. A similar synergistic effect between cellulase and xylanase in 
Table 2. In vitro DM digestibility (\%) and total sugar release (mg/100 g DM) from maize stover supplemented with various combinations of cellulase and xylanase

\begin{tabular}{|c|c|c|c|}
\hline \multicolumn{2}{|c|}{$\begin{array}{l}\text { Enzyme combination } \\
\text { (IU/g DM) }\end{array}$} & \multirow{2}{*}{$\begin{array}{c}\text { In vitro } \mathrm{DM} \\
\text { digestibility (\%) }\end{array}$} & \multirow{2}{*}{$\begin{array}{c}\text { In vitro sugar } \\
\text { release }(\mathrm{mg} / \mathrm{g} \mathrm{DM}\end{array}$} \\
\hline Cellulase & Xylanase & & \\
\hline 0 & 0 & $18.88^{i}$ & $3.08^{t}$ \\
\hline 0 & 12,800 & $22.29^{\mathrm{hi}}$ & $14.58^{\mathrm{pq}}$ \\
\hline 0 & 25,600 & $22.85^{\text {ghi }}$ & $15.70^{\mathrm{op}}$ \\
\hline 0 & 32,000 & $25.06^{\mathrm{ghi}}$ & $17.82^{\mathrm{mno}}$ \\
\hline 0 & 38,400 & $25.07^{\text {ghi }}$ & $18.20^{\mathrm{lmno}}$ \\
\hline 0 & 44,800 & $24.18^{\mathrm{ghi}}$ & $19.05^{\mathrm{lmn}}$ \\
\hline 6,400 & 0 & $20.61^{\text {hi }}$ & $9.16^{\mathrm{s}}$ \\
\hline 6,400 & 12,800 & $25.98^{\mathrm{gh}}$ & $16^{\text {nop }}$ \\
\hline 6,400 & 25,600 & $29.03^{\mathrm{fg}}$ & $25.59^{\mathrm{fgh}}$ \\
\hline 6,400 & 32,000 & $32.38^{\mathrm{ef}}$ & $26.68^{\mathrm{ef}}$ \\
\hline 6,400 & 38,400 & $33.08^{\text {def }}$ & $26.4^{\mathrm{ef}}$ \\
\hline 6,400 & 44,800 & $32.29^{\mathrm{ef}}$ & $23.10^{\text {ghij }}$ \\
\hline 12,800 & 0 & $21.31^{\mathrm{hi}}$ & $10.23^{\mathrm{rs}}$ \\
\hline 12,800 & 12,800 & $49.98^{\mathrm{a}}$ & $20.84^{\mathrm{jkl}}$ \\
\hline 12,800 & 25,600 & $38.63^{\text {cde }}$ & $21.05^{\mathrm{jkl}}$ \\
\hline 12,800 & 32,000 & $32.74^{\mathrm{def}}$ & $22.23^{\mathrm{ijk}}$ \\
\hline 12,800 & 38,400 & $39.03^{\text {cde }}$ & $22.59^{\mathrm{ijk}}$ \\
\hline 12,800 & 44,800 & $37.09^{\mathrm{def}}$ & $19.95^{\mathrm{klm}}$ \\
\hline 25,600 & 0 & $24.35^{\text {ghi }}$ & $12.74^{\mathrm{qr}}$ \\
\hline 25,600 & 12,800 & $45.89^{\mathrm{bc}}$ & $24.73^{\text {fghi }}$ \\
\hline 25,600 & 25,600 & $48.55^{\mathrm{ab}}$ & $25.92^{\mathrm{efg}}$ \\
\hline 25,600 & 32,000 & $32.03^{\mathrm{ef}}$ & $27.19^{\mathrm{ef}}$ \\
\hline 25,600 & 38,400 & $32.77^{\mathrm{def}}$ & $31.9^{c}$ \\
\hline 25,600 & 44,800 & $33.23^{\mathrm{def}}$ & $22.88^{\text {hijk }}$ \\
\hline 32,000 & 0 & $20.47^{\mathrm{hi}}$ & $14.38^{\mathrm{pq}}$ \\
\hline 32,000 & 12,800 & $41.9^{\mathrm{cd}}$ & $28.57^{\mathrm{de}}$ \\
\hline 32,000 & 25,600 & $46.00^{\mathrm{ab}}$ & $30.40^{\text {cd }}$ \\
\hline 32,000 & 32,000 & $21.25^{\mathrm{hi}}$ & $36.14^{\mathrm{b}}$ \\
\hline 32,000 & 38,400 & $22.59^{\text {ghi }}$ & $41.56^{\mathrm{a}}$ \\
\hline 32,000 & 44,800 & $11.57^{\mathrm{j}}$ & $36.81^{b}$ \\
\hline SEM & & 1.057 & 0.805 \\
\hline $\mathrm{p}$ value & & 0.001 & 0.001 \\
\hline \multicolumn{4}{|c|}{ Main factors } \\
\hline \multicolumn{4}{|c|}{ Cellulase } \\
\hline 0 & & $22.82^{\mathrm{d}}$ & $14.74^{\mathrm{e}}$ \\
\hline 6,400 & & $29.14^{\mathrm{e}}$ & $21.21^{\mathrm{c}}$ \\
\hline 12,800 & & $36.46^{\mathrm{a}}$ & $19.48^{\mathrm{d}}$ \\
\hline 25,600 & & $35.07^{\mathrm{ab}}$ & $24.23^{\mathrm{b}}$ \\
\hline 32,000 & & $29.60^{\mathrm{bc}}$ & $31.31^{\mathrm{a}}$ \\
\hline $\mathrm{p}$ value & & 0.001 & 0.001 \\
\hline \multicolumn{4}{|l|}{ Xylanase } \\
\hline 0 & & $20.72^{c}$ & $9.92^{\mathrm{f}}$ \\
\hline 12,800 & & $35.56^{\mathrm{a}}$ & $21.08^{\mathrm{e}}$ \\
\hline 25,600 & & $35.30^{\mathrm{b}}$ & $23.73^{\mathrm{d}}$ \\
\hline 32,000 & & $30.11^{\mathrm{b}}$ & $26.01^{\mathrm{b}}$ \\
\hline 38,400 & & $32.47^{\mathrm{ab}}$ & $28.06^{\mathrm{a}}$ \\
\hline 44,800 & & $29.54^{\mathrm{b}}$ & $24.36^{\mathrm{c}}$ \\
\hline $\mathrm{p}$ value & & 0.001 & 0.0010 \\
\hline
\end{tabular}

improving IVDMD from maize stover was observed in the present study when the ratio of cellulase and xylanase ranged between $1: 1$ and 1.25:1.

At all concentrations of cellulase $(6,400$ to $32,000 \mathrm{IU} / \mathrm{g}$ $\mathrm{DM})$ the in vitro sugar release increased $(\mathrm{p}<0.01)$ with xylanase concentrations (12,800 to $38,400 \mathrm{IU} / \mathrm{g}$ DM) but decreased at a xylanase concentration of 44,800 IU/g DM. Earlier studies also revealed that there was improvement in in vitro sugar (monosaccharide) release from paddy straw with increasing concentrations of cellulase (40,60 and 80 IU/g DM) but not with increasing concentrations of xylanase $(67,100$ and 133 IU/g DM) in cellulase-xylanase combination, and maximum monosaccharide release was observed with cellulase and xylanase doses of 80 and 100 IU/g DM, respectively when incubated for $24 \mathrm{~h}$ (Senthil kumar et al., 2007).

The cellulose-xylanase combinations IU/g selected for further studies with $\beta$-D glucanase were 12,800 to 12,800 followed by 25,600 to 25,600 and 25,600 to 12,800 . The $\beta$ D glucanase at concentrations of 100, 200 and $300 \mathrm{IU} / \mathrm{g}$ was supplemented to the ground maize stover along with above combinations to study the synergistic effect of $\beta-D$ glucanase and the results are presented in Table 3.

Supplementation of $\beta$-D glucanase from 100 to 300 IU/g had no beneficial effect on IVDMD and the values were comparable to the combination having no $\beta-\mathrm{D}$ glucanase. While for the combination $(25,600$ IU cellulase 12,800 IU xylanase/g, 25,600 IU cellulase - 25,600 IU xylanase/g), supplementation of $\beta$-D glucanase at $300 \mathrm{IU} / \mathrm{g}$ depressed IVDMD. The IVDMD was highest for cellulasexylanase- $\beta$-D glucanase IU/g combination 25,600-25,600-0, followed by $25,600-12,800-0$ and $12,800-12,800-0$ with values of $52.15,51.21$ and $49.80 \%$, respectively. On the other hand, Eun et al. (2007) reported increased NDF degradability of both alfalfa hay and corn silage with addition of endoglucanase (301 IU/g DM) to xylanase (693 IU/g DM).

The reason for the lack of response with addition of $\beta-D$ glucanase in the present study was unclear. This might be due to a sub-optimal dose or to the cell wall structure of the maize stover which would be in agreement with Jalilvand et al. (2008) who observed that responses to level of enzyme addition (12,600 IU cellulase, 7,500 IU xylanase, 1,500 IU $\beta$-D glucanase/g) differed with forage type, the level of enzyme application and reported that addition of high levels was less effective than low levels. Based on the in vitro studies, the combination cellulase-xylanase- $\beta$-D glucanase 25,600-25,600-0 IU/g, had highest IVDMD (52.15\%) and was comparable to the combination $12,800-12,800-0$ and therefore the latter combination was selected to study the effect of this enzyme cocktail on rumen metabolites in sheep fed 50\% maize stover based TMR. 
Table 3. In vitro DM digestibility (\%) and total sugar release ( $\mathrm{mg} / \mathrm{g} \mathrm{DM})$ maize stover supplemented with various combinations of cellulase and xylanase

\begin{tabular}{|c|c|c|c|c|}
\hline \multicolumn{3}{|c|}{ Enzyme combination (IU/g DM) } & \multirow{2}{*}{ In vitro DM digestibility (\%) } & \multirow{2}{*}{ In vitro sugar release (mg/g DM) } \\
\hline Cellulase & Xylanase & $\beta$-D Glucanase & & \\
\hline 0 & 0 & 0 & $18.91^{\mathrm{e}}$ & $3.08^{\mathrm{e}}$ \\
\hline 12,800 & 12,800 & 0 & $49.80^{\mathrm{ab}}$ & $20.84^{c}$ \\
\hline 12,800 & 12,800 & 100 & $47.73^{\mathrm{abcd}}$ & $29.37^{c}$ \\
\hline 12,800 & 12,800 & 200 & $49.11^{\mathrm{abc}}$ & $32.60^{\mathrm{bc}}$ \\
\hline 12,800 & 12,800 & 300 & $47.88^{\mathrm{abcd}}$ & $38.23^{\mathrm{a}}$ \\
\hline 25,600 & 12,800 & 0 & $51.21^{\mathrm{ab}}$ & $24.73^{\mathrm{d}}$ \\
\hline 25,600 & 12,800 & 100 & $46.85^{\mathrm{abcd}}$ & $31.18^{\mathrm{bc}}$ \\
\hline 25,600 & 12,800 & 200 & $45.95^{\mathrm{abcd}}$ & $32.09^{\mathrm{bc}}$ \\
\hline 25,600 & 12,800 & 300 & $42.54^{\mathrm{cd}}$ & $34.42^{\mathrm{b}}$ \\
\hline 25,600 & 25,600 & 0 & $52.15^{\mathrm{a}}$ & $25.92^{\mathrm{d}}$ \\
\hline 25,600 & 25,600 & 100 & $46.07^{\mathrm{abcd}}$ & $33.54^{\mathrm{b}}$ \\
\hline 25,600 & 25,600 & 200 & $44.15^{\mathrm{bcd}}$ & $33.29^{\mathrm{b}}$ \\
\hline 25,600 & 25,600 & 300 & $41.73^{\mathrm{d}}$ & $37.78^{\mathrm{a}}$ \\
\hline SEM & & & 1.667 & 0.782 \\
\hline$p$ value & & & 0.001 & 0.001 \\
\hline
\end{tabular}

${ }^{\mathrm{a}-\mathrm{d}}$ Means with different superscripts in a column differ significantly: $\mathrm{p}<0.01$.

Each value is average of triplicate; $\mathrm{SEM}=$ Standard error of means.

\section{Dry matter intake and rumen fermentation pattern}

There was no significant difference in the initial and final body weights in each group, during the experiment. The dry matter intake of un-supplemented and enzyme supplemented maize stover based TMR was $632.69 \mathrm{~g} / \mathrm{d}$ and $602.71 \mathrm{~g} / \mathrm{d}$, respectively. There was no significant difference in the average feed intake of dry matter $\mathrm{g} / \mathrm{kg}$ $\mathrm{W}^{0.75}$ ) by supplementing the enzyme cocktail to $50 \%$ maize stover based TMR, indicating that the sheep of both groups were maintained on same plane of nutrition (Table 4).

Supplementing the above selected enzyme cocktail had a significant effect on TVFA and $\mathrm{NH}_{3}-\mathrm{N}$ concentration in sheep fed $50 \%$ maize stover based TMR, though no interaction of enzyme supplementation and period of rumen liquor collection was observed. The higher TVFA with enzyme addition could be result of higher availability of fermentable soluble carbohydrates due to increased fibrolytic activity in rumen. Hristov et al. (2000) reported

Table 4. Rumen fermentation pattern in lambs fed maize stover based TMR supplemented with EFE

\begin{tabular}{|c|c|c|c|c|c|}
\hline Attribute & TMR-MS & TMR-MS+EFE & & TMR-MS & TMR-MS+EFE \\
\hline \multicolumn{3}{|l|}{ Body weights (kg) } & \multicolumn{3}{|c|}{ Total nitrogen $(\mathrm{mg} / 100 \mathrm{ml})$} \\
\hline Initial & $20.07 \pm 3.447$ & $20.30 \pm 3.637$ & $0 \mathrm{~h}$ & $173.88 \pm 29.181$ & $186.88 \pm 14.879$ \\
\hline Final & $20.22 \pm 3.431$ & $20.47 \pm 3.595$ & $2 \mathrm{~h}$ & $234.88 \pm 21.877$ & $193.50 \pm 12.553$ \\
\hline \multicolumn{3}{|c|}{ Average intake ( $\left.\mathrm{g} / \mathrm{kg} \mathrm{W}^{0.75}\right)$} & $4 \mathrm{~h}$ & $288.50 \pm 21.154$ & $284.63 \pm 13.677$ \\
\hline Dry matter & $71.46 \pm 8.53$ & $68.36 \pm 8.36$ & $6 \mathrm{~h}$ & $266.13 \pm 30.681$ & $233.75 \pm 14.833$ \\
\hline \multicolumn{3}{|l|}{ Ruminal pH } & Mean $(\mathrm{p}<0.280)$ & $240.84 \pm 14.609$ & $224.69 \pm 9.663$ \\
\hline $0 \mathrm{~h}$ & $6.39 \pm 0.370$ & $6.18 \pm 0.366$ & \multicolumn{3}{|c|}{ Ammonia nitrogen $(\mathrm{mg} / 100 \mathrm{ml})$} \\
\hline $2 \mathrm{~h}$ & $5.99 \pm 0.293$ & $5.73 \pm 0.32$ & $0 \mathrm{~h}$ & $14.90 \pm 0.770$ & $16.50 \pm 1.614$ \\
\hline $4 \mathrm{~h}$ & $5.24 \pm 0.148$ & $4.99 \pm 0.10$ & $2 \mathrm{~h}$ & $21.60 \pm 1.190$ & $22.00 \pm 1.301$ \\
\hline $6 \mathrm{~h}$ & $5.00 \pm 0.087$ & $4.77 \pm 0.054$ & $4 \mathrm{~h}$ & $25.70 \pm 2.463$ & $31.30 \pm 1.37$ \\
\hline Mean $(\mathrm{p}<0.185)$ & $5.65 \pm 0.156$ & $5.42 \pm 0.156$ & $6 \mathrm{~h}$ & $19.20 \pm 1.710$ & $25.00 \pm 2.049$ \\
\hline \multicolumn{3}{|c|}{ Total volatile fatty acids (meq/100 ml) } & Mean $(\mathrm{p}<0.005)$ & $20.35 \pm 1.056^{\mathrm{b}}$ & $23.70 \pm 1.288^{\mathrm{a}}$ \\
\hline $0 \mathrm{~h}$ & $14.63 \pm 0.844$ & $18.00 \pm 1.150$ & & & \\
\hline $2 \mathrm{~h}$ & $21.00 \pm 0.802$ & $21.75 \pm 1.16$ & & & \\
\hline $4 \mathrm{~h}$ & $26.88 \pm 0.875$ & $30.25 \pm 0.940$ & & & \\
\hline $6 \mathrm{~h}$ & $24.38 \pm 0.822$ & $26.25 \pm 0.959$ & & & \\
\hline Mean $(\mathrm{p}<0.001)$ & $21.72 \pm 0.916^{\mathrm{b}}$ & $24.06 \pm 0.969^{\mathrm{a}}$ & & & \\
\hline
\end{tabular}

${ }^{\mathrm{ab}}$ Means bearing different superscripts in a row and sub-column differ significantly: $\mathrm{p}<0.01 ; \mathrm{p}<0.05$.

$\mathrm{SEM}=$ Standard error of means; $\mathrm{MS}=$ Maize stover EFE $=$ Exogenous fibrolytic enzyme; $\mathrm{TMR}=$ Total mixed ration. 
an increase in TVFA concentration in heifers fed on a barley silage based diet supplemented with EFE. Similarly, increased TVFA concentration in rumen of lambs with intra-ruminal supplementation of $5 \mathrm{~g}$ fibrozyme was reported by Pinos Rodriguez et al. (2008). The average values of ruminal $\mathrm{pH}$, irrespective of ration fell after $2 \mathrm{~h}$ post feeding and continued to decline until $6 \mathrm{~h}$ after feeding. The decline in the ruminal $\mathrm{pH}$ values with EFE supplementation was due to increased TVFA concentration. The peak TVFA, ammonia nitrogen and total nitrogen concentrations in the ruminal fluid $(\mathrm{p}<0.01)$ was observed at $4 \mathrm{~h}$ post feeding irrespective of rations and fell at $6 \mathrm{~h}$ post feeding (Table 4). Avellaneda et al. (2009) reported a significant increase $(\mathrm{p}<0.01)$ in ammonia nitrogen concentration in rumen liquor of lambs fed on guinea grass supplemented with enzyme (having 100 xylose units/g) at 3 $\mathrm{g} / \mathrm{d} / \mathrm{lamb}$ corroborating the present findings.

\section{CONCLUSION}

The exogenous fibrolytic enzymes cellulase and xylanase supplemented singly or in combinations increased in vitro DM digestibility and in vitro sugar release but supplementation of $\beta$-D glucanase along with cellulase and xylanase had no synergistic effect. Based on the in vitro studies, the fibrolytic enzymes combination cellulasexylanase- $\beta$-D-glucanase $\quad 25,600-25,600-0 \quad$ IU/g was optimum for enhancing nutrient utilization from maize stover and supplementation of cellulase-xylanase- $\beta$-Dglucanase $12,800-12,800-0 \mathrm{IU} / \mathrm{g}$ to sheep fed $50 \%$ maize stover based TMR increased the TVFA and $\mathrm{NH}_{3}-\mathrm{N}$ concentration in rumen.

\section{REFERENCES}

AOAC. 1997 Official methods of analysis, 16th Edition. Association of Official Analytical Chemists, Maryland.

Bhat, M. K., and G. P. Hazelwood. 2001. Enzymology and other characteristics of cellulases and xylanases: Enzymes in Farm Animal Nutrition. Bedford $M$ and Partridge $G$ CABI Publishing, Oxon, UK.

Barnett, A. J. G., and R. L. Reid. 1957. Studies on the production of volatile fatty acids from grass by rumen liquor in an artificial rumen and the volatile fatty acid production from grass. J. Agric. Sci. Cam. 48:315-321.

Colombatto, D., R. L. Mould, M. K. Bhat, D. P. Morgavi, K. A. Beauchemin, and E. Owen. 2003. Influence of fibrolytic enzymes on the hydrolysis and fermentation of pure cellulose and xylan by mixed ruminal microorganisms in vitro. J. Anim. Sci. 81:1040-1050.

Dubois, M., K. A Gilles, J. K Hamilton, P. A. Rebers, and F. Smith. 1956. Colorimetric method for determination of sugars and related substances. Anal. Biochem. 28:350-356.

Duncan, D. B. 1955 Multiple range and multiple F-tests. Biometrics 11:1-42.
Eun, J. S., and K. A. Beauchemin. 2007. Enhancing in vitro degradation of alfalfa hay and corn silage using feed enzymes. J. Dairy Sci. 90:2839-2851.

Eun, J. S., K. A. Beauchemin, and H. Schulze. 2007. Use of exogenous fibrolytic enzymes to enhance in vitro fermentation of alfalfa hay and corn silage. J. Dairy Sci. 90:1440-1451.

Gallardo, I., R. Bárcena, J. M. Pinos-Rodríguez, M. Cobos, L. Carreón, and M. Ortega. 2010. Influence of exogenous fibrolytic enzymes on in vitro and in sacco degradation of forages for ruminants. Ital. J. Anim. Sci. 9:34-38.

Giraldo, L. A., M. L. Tejido, M. J. Ranilla, and M. D. Carro. 2008. Effects of exogenous fibrolytic enzymes on in vitro ruminal fermentation of substrates with different forage: concentrate ratios. Anim. Feed Sci. Technol. 141:306-325.

Goering, H. K., and P. J. Van Soest. 1970. Forage Fiber Analysis (Apparatus, Reagents, Procedures and some applications) USDA, Agricultural Handbook No. 379.

Hristov, A. N., T. A. McAllister, and K. J. Cheng. 2000. Intraruminal supplementation with increasing levels of exogenous polysaccharides-degrading enzymes: effects on nutrient degradation in cattle fed barley grain diet. J. Anim. Sci. 78: 477-487.

ICAR. 1998. Nutrient requirements of sheep. Indian Council of Agricultural Research, New Delhi, India.

Jalilvand, G., N. E. Odongo, S. López, A. Naserian, R. Valizadeh, F. Eftekhar Shahrodi, E. Kebreab, and J. France. 2008. Effects of different levels of an enzyme mixture on in vitro gas production parameters of contrasting forages. Anim. Feed Sci. Technol. 146:289-301.

McAllister, S. K., H. D. Bae, R. J. Treache, A. N. Hristov, J. Baah, J. A. Shelford, and K. J. Cheng. 2000. Effect of a surfactant and exogenous enzymes on digestibility of feed and on growth performance and carcass traits of lambs. Can. J. Anim. Sci. 80:35-44.

Morgavi, D. P., K. A. Beauchemin, V. L. Nsereko, L. M. Rode, A. D. Iwaasa, W. Z. Yanq, T. A. McAllister, and Y. Wang. 2000. Synergy between ruminal fibrolytic enzymes and enzymes from Trichoderma longibrachiatum. J. Dairy Sci. 83:13101321.

Nakashima, Y., E. R. Orskov, P. M. Hotten, K. Ambo, and Y. Takase. 1988. Rumen degradation of straw-6. Effect of polysaccharidase enzymes on degradation characteristics of ensiled rice straw. Anim. Prod. 47:421-427.

Nsereko, V. L. 2000. Effects of fungal enzyme from the rumen, preparations on hydrolysis and subsequent degradation of alfalfa hay fiber by mixed rumen microorganisms in vitro. Anim. Feed Sci. Technol. 88:153-170.

Pinos Rodriguez, J. M., R. Moreno, S. S. Gonzalez, P. H. Robinson, G. Mendoza, and G. Alvarez. 2008. Effects of exogenous fibrolytic enzymes on ruminal fermentation and digestibilty of total mixed rations fed to lambs. Anim. Feed Sci. Technol. 142:210-219.

Pinos-Rodriguez, J. M., S. S. Gonzalez, G. D. Mendoza, R. Barcena, M. A. Cobos, A. Hernandez, and M. E. Ortega. 2002. Effect of exogenous fibrolytic enzyme on ruminal fermentation and digestibility of alfalfa and rye-grass hay fed to lambs. J. Anim. Sci. 80:3016-3020.

Singh, A. K., P. N. Sudarshan, G. S. Langer, A. S. Sidhu Kochar, and Bhatia.1968. Study of rumen biochemical activity in the 
buffaloes and Zebu cattle under non urea feeding regimens. Ind. J. Vet. Sci. Anim. Husb. 38:674-681.

Swartz, H. M., and C. A. Schoeman. 1964. Utilization of urea by sheep. I. Rates of breakdown urea and carbohydrates in vivo and in vitro. J. Agric. Sci. 63:289-296.

Senthilkumar, S., C. Valli, and V. Balakrishnan. 2007. Evolving specific non starch polysaccharide enzyme mix to paddy straw for enhancing its nutritive value. Livest. Res. Rural Dev. 19:112.

Waghorn, G. C., and W. C. McNabb. 2003. Consequences of plant phenolic compounds for productivity and health of ruminants. Proc. Nutr. Soc. 62:383-392.
Wang, Y., B. M. Spratling, D. R. Zobell, R. D. Wiedmeier, and T. A. McAllister. 2004. Effect of alkali pretreatment of wheat straw on the efficacy of exogenous fibrolytic enzymes. J. Anim. Sci. 82:198-208.

Yang, W. Z., K. A. Beauchemin, and L. M. Rode. 1999. Effects of an enzyme feed additive on extent of digestion and milk production of lactating dairy cows. J. Dairy Sci. 82:391-403.

Yu, P., J. J. Mc Kinnon, and D. A. Christensen. 2005. Improving the nutritive value of oat hulls for ruminant animals with pretreatment of a multi-enzyme cocktail: In vitro studies. J. Anim. Sci. 83:1133-1141. 